\title{
Research on the Evaluation Indicators of Skilled Employees' Career Success Based on Grounded Theory
}

\author{
Fulei Chu, Long Ye, Ming Guo \\ Beijing Jiatong University, School of Economics and Management (China) \\ fuleicbu@bjitu.edu.cn,.yelong@,bjtu.edu.cn,.gming@bitu.edu.cn
}

Received: January 2015

Accepted: April 2015

\section{Abstract:}

Purpose: Summarized and sorted career success evaluation indicators of skilled employees.

Design/methodology/approach: Based on Grounded Theory, through interviews and questionnaires to railway skilled employees.

Findings: the study shows that "subjective career success", including work-family balance, life satisfaction, career satisfaction, perception of career success, "objective career success", including level of total revenue venue, growth rate of wage and times of promotion, "knowledge and skills career success" including upgrade of knowledge and skills, classification of skills, external competitiveness and job autonomy, are three important career success evaluation indicators of skilled employees.

Originality/value: The results show that different age groups, different titles and different positions of skilled employees, there is a significant difference in the choice of career success evaluation indicators. It provides a useful reference to establish a career development system for the skilled employees.

Keywords: skilled employees, career success, evaluation indicators, railway industry 


\section{Introduction}

Since the beginning of the 21st century, the United States, Britain and other countries have a shortage of skills (skill shortage) phenomenon. To ease the supply and demand pressures, Canada, Australia, New Zealand and other countries take "skilled migrants" to fill the employment gap. Many countries desperately take the shortage of type of talents as a priority object in the development of technical immigration policy, such as Australia, Canada, which favoring IT engineers and accountants. In recent years, with the intensification of the process of global economic integration and international industrial transform, the shortage of skilled employees began to "spread" to the "BRIC countries" which represent emerging economies. As a result, "the skills shortage" began to become a worldwide issue, and the training of skilled employees caused widespread concern around the world. With the rapid development of China's economy, skilled employees are playing an increasingly important role in economic construction, and have become an indispensable force both in promoting technological innovation and realizing transformation of scientific and technological achievements. In the traditional management practices of skilled employees in China, due to the lack of adequate career development paths, railway skilled employees with outstanding performance were only promoted to management positions to get professional development, and access to career success. Career success, the accomplishment of desirable work-related outcomes over time (Arthur, Khapova \& Wilderom, 2005), is accordingly among the most important outcome variables in career research, pursuit of career success is innermost desire of everyone of career development, is also the starting point and destination of career theoretical study, skilled employees is no exception.

\section{Research Review}

The meaning of career success varies from person to person, is very relative. The more recognized definition of career success, is that the career success is accumulated in a positive psychological or work-related outcomes or achievement proposed by London and Stumpf (1982). In the academic literature of the West, career success is usually explored from two aspects: subjective and objective. Objective career success can be observed and evaluated, confirmed by a third party without prejudice, such as high income, the illustrious title, duties, high social prestige and status. And subjective career success refers to subjective feeling and satisfaction of career completion, or personal positive psychological feelings of gradual accumulation of work experience (Van Maanen, 1977; Heslin, 2005). Putting subjective and objective aspects together not only reflects the success of a universal standard, but also reflects subjective feelings of personal goals and career expectations (Hall \& Chandler, 2005). Arthur and Rousseau (1996) found that more than $75 \%$ articles with career success published in the years 1980-1994 studying career success from the point of view of the objective criteria. 
However, as careers becoming increasingly boundaryless, researchers may increasingly evaluate career success based on subjectively standards (Dries, Pepermans \& Carlier, 2008). As a result, the interest in subjective career success has risen obviously in recent years (Heslin, 2005; Verbruggen, 2012). With the rise of the borderless career, more and more scholars build the evaluation indicators of career success from both subjective and objective (Judge, Higgins, Thoresen \& Barrick, 1999; Jansen \& Vinkenburg, 2006).

Although scholars have did a lot of research and discussion in the evaluation of career success, but overall there is the following insignificancy:

- most of the research object is for all employees, not distinguishes the nature of the work according to the different groups;

- most of the studies using the questionnaire method, there are little depth interviews and other qualitative research methods.

- The research and explore of career success evaluation indicators in the context of Chinese culture is exile.

Due to the special nature of culture, research carried out in the context of Chinese culture may come to different conclusions. Especially for skilled employees, the current study is mainly focused on two aspects: the macro-level of market supply and demand of skilled employees, the structure of skilled employees and the distribution of skilled employees; micro-level of human capital of skilled employees, such as learning, education and training of skilled employees, as well as the professional quality of the skilled employees. Little research from the perspective of career development and career success.

In this study, we take the railway skilled employees for example, based on Grounded Theory, research and explore the evaluation indicators of career success of skilled employees combined with interviews and questionnaires. Although each of the evaluation indicators of the career success may be different, but we believe a common cultural background and the nature of the work of skilled employees can also cause the convergence of values and ideas, ways of thinking of this group. The purpose of the survey is not to find out all of the evaluation indicators, but to find out the more important evaluation indicators that most people thinking about.

\section{Design of the Research}

In the study, we will take railway industry for example. Railway skilled employees refers that in the first-line of rail transport positions, acquiring expertise and technology, with a certain degree of operational skills, and can be able to use their own technology and ability to carry 
out the actual operational work, mainly including the technologists and other talents with appropriate level skills. In actual investigation, we selected the EMU drivers, EMU mechanics and dispatchers as samples to take data collection.

In the specific research process, first through literature analysis to identify the main evaluation of career success; then analyze railway skilled employees' evaluation indicators of career success based on Grounded Theory; third, draw up "questionnaires of railway skilled employees' evaluation indicators of career success", and deliver questionnaires to the EMU drivers, EMU mechanic and dispatcher, and finally get the railway skilled employees' evaluation indicators of career success.

\subsection{Literature Statistics}

According to attribution theory (cognitive theory), it is easy to attribute success to internal factors and failures to external factors, therefore, employees with objective success are likely to have a positive self-concept, and in turn promote their career satisfaction, social comparison theory also reached the similar conclusion. According to the theory, it is easy to compare yourself with others, salary levels and promotion are important and easy scales, once employees have gained a higher salary levels and more promotion, they may produce awareness of personal success, because wealth and social status in the society can be measured, so salary levels and promotion become important objective evaluation of success in the literature. This study count the numbers of evaluation indicators of Arthur et al. (2005), as shown in Figure 1, it can be seen that objective evaluation indicators is concentrated, total income level $(26.5 \%)$, salary or salary increase $(35.3 \%)$, promotion including promotion times or speed $(36.8 \%)$, compensation $(11.8 \%)$, management level $(10.3 \%)$ and status $(5.9 \%)$ are important indicators.

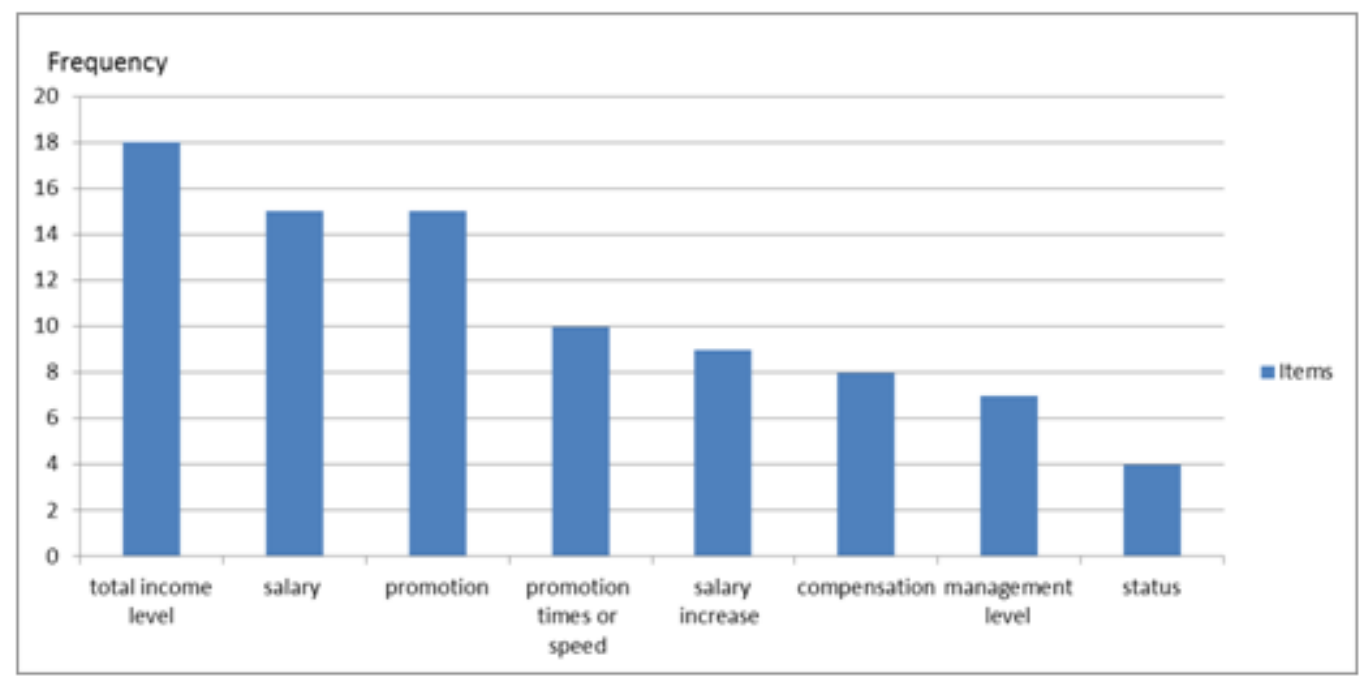

Figure 1. The evaluation index statistics of objective career success from Arthur et al. (2005) 
Employees in modern enterprise organizations increasingly have diversified career goals, in addition to material benefits, they may pay more attention to the interest and challenge of work, and want to have the opportunity to grow and develop, to access subjective career success. From counting the numbers of subjective evaluation indicators of Arthur et al. (2005), career satisfaction $(32.3 \%)$, job satisfaction $(23.5 \%)$, perceived career success and career advancement $(14.7 \%)$, professional sense of participation $(10.3 \%)$, life satisfaction $(7.4 \%)$ are the main subjective evaluation indicators (see Figure 2).

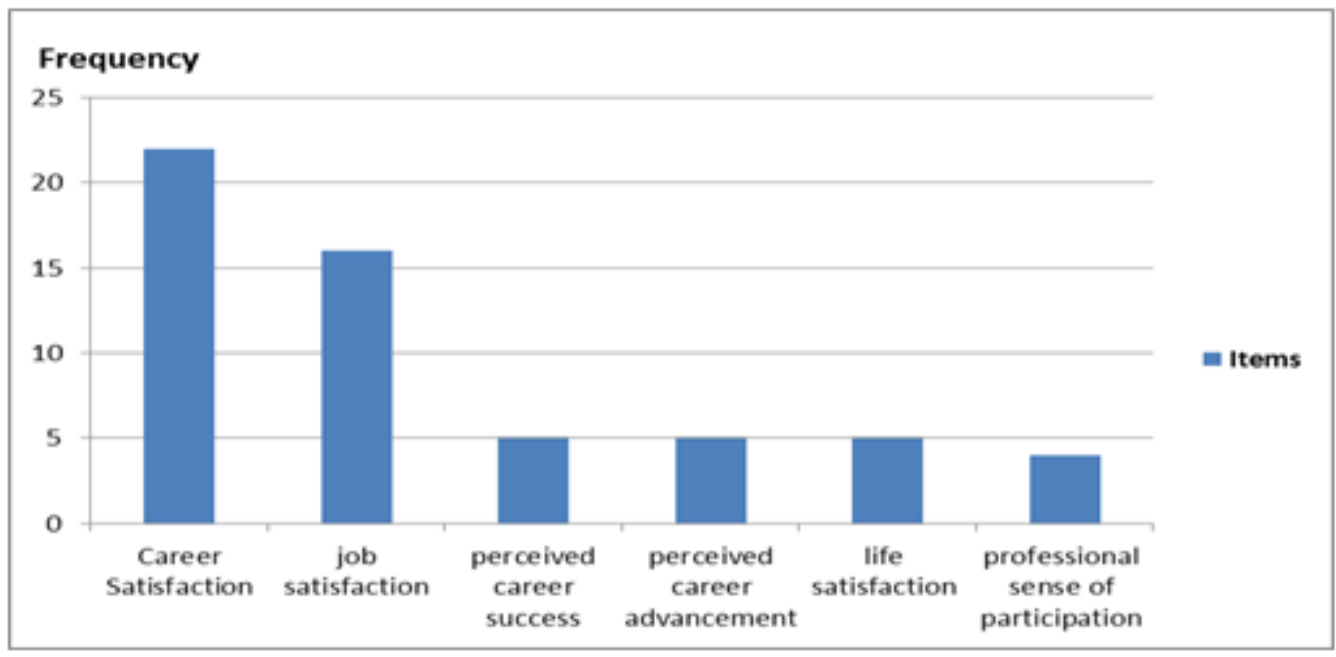

Figure 2. The evaluation index statistics of subjective career success from Arthur et al. (2005)

Since then, Nicholson and Waal-Andrews (2005) conducted in-depth research on the evaluation indicators of objective and subjective career success, he said that there was a logic and functional link between the objective and subjective career success, and pointed out that the subjective career success included job or career satisfaction (self-identity, spiritual fulfillment); objective career success included: the status and title (grade position); material success (wealth, property, earning capacity); social prestige and respect, prestige and influence; knowledge and skills; friendship, social networking; health and happiness.

After that, the majority of scholars analyzed objective and subjective career success based on the above evaluation indicators to study these two scholars on the basis of objective and subjective career success factors were analyzed, such as Pachulicz, Schmitt and Kuljanin (2008) studied the emergency room doctor's evaluation indicators of career success, career satisfaction as subjective evaluation indicator, academic leadership role, the number of leading medical communities as well as salary growth rate as objective evaluation indicators; Verbruggen (2012) studied the impact of psychological mobility to career success under the new "career climate", and put career satisfaction and job satisfaction, salary and promotion as subjective and objective career success evaluation indicators respectively. 


\subsection{Design of Grounded Theory}

As a research method of qualitative, the aim of grounded theory is to establish a theory from data on the basis of experience, and is a bottom-up approach to establish the substance of the theory. Grounded theory provides a standardized operating procedures of the data analysis, and establishes three coding procedures, including open coding, axial coding, selective coding.

\subsubsection{Sample Selection and Interview Process}

It has been outlined that career success has two aspects, objective and subjective, Consequently, information on both was collected in this study. Objective career success, describing an external perspective on individuals' careers, is generally assessed by means of pay, promotion or position. Subject career success describes individuals' own perceptions of their careers measured against personal standards. Often, it is not clear what to assess these individual standards upon. There are not only differences between individuals' concept of career, but also the question of the reference group arises (Heslin, 2005). Various measures of subject career success guide there respondent to answer in exclusively intra-organizational terms.

Before the beginning of the formal interview, we first explained the purpose and plan of this interview to the respondents, and told them why they were chosen as interview subjects, the importance of their answers to this study and the treatment of the interview results. Each interview lasted for 40-50 minutes, after the consent of the interviewees, we recorded the whole process of the interview with a voice recorder, after the end of the interview, we immediately made the sound recording into text data.

According to the methods required for depth and semi-structured interview for collecting information of grounded theory, we prepared the corresponding interview outline, the content of this interview including:

- The basic information of interviewees (marital status, education, technical grade, age, income, etc.).

- Whether career success is important for you? What factors do skilled employees' career success depends on? What is the criteria of career success in your idea? what do you have to make you think that you have achieved career success?

- How do you know and think about railway industry, and how to develop your career in this industry? 
- Can you cite a person on your side with successful career? Why do you think he/she is successful? And so on.

The questions and outline listed above just served as a reminder and guide role, in the specific interview process, we still adhered to a flexible and open-minded, and used different questioning manner and order varies from person to person.

This study selected 20 skilled personnel as the object of this interview (for convenience statistics, interviews with personnel numbered G1-G20) from the Beijing Railway Bureau, the interview process including: getting in touch with the Beijing Railway Bureau and Tangshan Locomotive segment one week prior to the interview, and coordinating specific time and place of the interview, and the two interviewers separately interviewed the subjects in separate rooms. The 20 skilled employees are in compliance with this research requirement, they are all belong to the railway industry, with a wealth of experience and good skills, voluntarily take part in the interview and have their own understanding of career success. The following table is a distribution of 20 members interviewed (see Table 1).

\begin{tabular}{|l|l|r|r|}
\hline \multicolumn{1}{c}{ Item } & \multicolumn{1}{c|}{ Options } & Number & \multicolumn{1}{c|}{ Percentage } \\
\hline \multirow{2}{*}{ Gender } & Male & 16 & $80 \%$ \\
\cline { 2 - 4 } & Female & 4 & $20 \%$ \\
\hline \multirow{3}{*}{ Marital Status } & Married & 17 & $85 \%$ \\
\cline { 2 - 4 } & Unmarried & 3 & $15 \%$ \\
\hline \multirow{5}{*}{ Age } & Less than 30 years old & 3 & $15 \%$ \\
\cline { 2 - 4 } & $31-35$ years old & 4 & $20 \%$ \\
\cline { 2 - 4 } & $36-40$ years old & 7 & $35 \%$ \\
\cline { 2 - 5 } & $41-45$ years old & 3 & $15 \%$ \\
\cline { 2 - 5 } & $46-50$ years old & 3 & $15 \%$ \\
\hline \multirow{3}{*}{ Skill Level } & Junior Technician & 5 & $25 \%$ \\
\cline { 2 - 5 } & Intermediate technicians & 7 & $35 \%$ \\
\cline { 2 - 5 } & Senior Technician & 8 & $40 \%$ \\
\hline
\end{tabular}

Table 1. Distribution characteristics of interview personnel

\subsubsection{Analysis}

The data was content-analyzed, we used open coding, axial coding, selective coding to analyzed the data. In the open coding phase, we extracted a total of 41 representative phenomenon (label) from 20 parts about 110,000 words of the interview data. Based on this phenomenon, we conceptualized them and decomposed them to 22 independent cases, ideas, events and actions.

After the open coding, we conducted axial coding. Axial coding is assembling concepts and categories formed in open coding together, in fact, these two codes do not have an absolute order, since in the open coding, some concepts has begun to link in the mind. In the open coding of the railway skilled employees' career success, we finally got the 14 categories of employees' career success. 
Finally, we conducted selective coding, it also means finding core categories. The discovery of core categories, mainly indicates summarizing and scouring categories which have been found in the axial coding, and thus we got three main areas. After open coding, axial coding, selective coding with 20 parts about 11 million words of original interviews we got 15 basic categories, three main areas of the skilled employees' career success.

We got the evaluation indicates of railway skilled employees' career success through analyzing the interview data based on grounded theory. Since the study is inductive analysis of the information based on interview data, therefore, whether the information is adequate or not will impact on the conclusion directly. In order to ensure adequate and reliable of the results, we will verify these conclusions by questionnaires.

\subsection{Investigation of Questionnaire}

On the basis of interviews, we will sort the evaluation indicators of career success of skilled employees mentioned above with questionnaires, and can further and in-depth understanding the main evaluation indicators of career success in the Chinese context. A structured questionnaire is designed to make the skilled employees answer how to sort the eight indicators. In order to avoid deviation at understanding the indicators, we made detailed explanation in the questionnaire for each standard. The survey was taken by convenient sampling, and face-to-face, so it is easy to answer the issues raised by the skilled employees at any time. Questionnaire is made with Liket- 5 scale, " 5 " is on behalf of "very important" and " 1 " is on behalf of "very unimportant".

The questionnaires were assigned to skilled employees of the railway industry parts,495 copies were returned, and 460 copies are valid, the valid rate is $92.9 \%$. And specific statistical characteristics of participants were shown in Table 2.

\begin{tabular}{|c|c|c|c|}
\hline & EMU Drivers & EMU Mechanics & Dispatchers \\
\hline Total & accounted for $37.6 \%$ & accounted for $32.6 \%$ & accounted for $29.8 \%$ \\
\hline Gender & Male accounted for $86.5 \%$ & Female accounted for $14.5 \%$ & \\
\hline \multirow{4}{*}{ Age } & $25-30$ years old & accounted for $10.1 \%$ & \\
\hline & $30-35$ years old & accounted for $35.4 \%$ & \\
\hline & $35-40$ years old & accounted for $40.1 \%$ & \\
\hline & $40-45$ years old & accounted for $14.4 \%$ & \\
\hline \multirow{3}{*}{ Titles } & Senior technician & accounted for $32.8 \%$ & \\
\hline & Intermediate technicians & accounted for $49.4 \%$ & \\
\hline & Junior Technician & accounted for $17.8 \%$ & \\
\hline
\end{tabular}

Table 2. Specific statistical characteristics of participants 


\section{Result}

\subsection{Descriptive Statistical Analysis}

Analyzing the returned questionnaires, and organizing the data, we obtained the important score of each evaluation indicators of career success of skilled employees in Table 3.

\begin{tabular}{|c|c|c|c|c|c|}
\hline Index & Mean & Sd. & Index & Mean & Sd. \\
\hline work-family balance & 4.44 & 1.094 & $\begin{array}{l}\text { organizational } \\
\text { commitment }\end{array}$ & 3.78 & 1.006 \\
\hline \multirow{2}{*}{$\begin{array}{l}\text { classification of skills } \\
\text { upgrade of } \\
\text { knowledge and kills }\end{array}$} & 4.32 & 092 & \multirow{2}{*}{$\begin{array}{l}\text { growth rate of wage } \\
\text { external } \\
\text { competitiveness }\end{array}$} & 3.75 & 1.164 \\
\hline & 4.27 & 15 & & 3.54 & 135 \\
\hline life satisfact & 4.27 & 1 & $\begin{array}{l}\text { internal } \\
\text { competitiveness }\end{array}$ & 3.53 & 1.097 \\
\hline $\begin{array}{l}\text { level of total revenue } \\
\text { venue }\end{array}$ & 4.24 & 1.125 & times of promotion & 3.38 & 1.124 \\
\hline career satisfa & 4.03 & 1.095 & & 3.21 & 1.016 \\
\hline $\begin{array}{l}\text { perception of career } \\
\text { success }\end{array}$ & 3.82 & 1.124 & $\begin{array}{l}\text { power of } \\
\text { management }\end{array}$ & 3.16 & 1.223 \\
\hline
\end{tabular}

Table 3. Descriptive statistical analysis of career success of skilled employees

As can be seen from the Table 3, the scores of work-family balance, classification of skills, upgrade of knowledge and skills, life satisfaction, level of total revenue and career satisfaction are more than 4, that is, the 6 indexes are the most important standard of career success for skilled employees. But other indexes' scores are also more than 3, so it points that the evaluation indicators of career success of skilled employees listed above are agreeable.

\subsection{EFA and CFA of Skilled Employees' Career Success}

To test the reliability and validity of measurement model, we will use exploratory factor analysis (EFA) and confirmatory factor analysis (CFA). EFA means to find groups of variables which can represent the underlying dimension, and finding the relationships between observed measures and their posited underlying factors is the aim of CFA. We divide the data into two equal parts, one part for exploratory factor analysis (EFA), and the other for confirmatory factor analysis (CFA). The KMO of sample is 0.897, Bartlett spherical inspection value is $1401.877, \mathrm{p}<0.000$, reached a significant level, show that suitable for EFA.

EFA results extracted three factors with Cronbach's alpha ranging from 0.712 to 0.835 , exceeding the minimum standard for reliability $(0.70)$ recommended by Nunnally and Bernstein (1978). Deleted 3 items that their loading estimates had not exceeded 0.5. The items explained $65.09 \%$ of the overall variance. The data is shown in Table 4. 


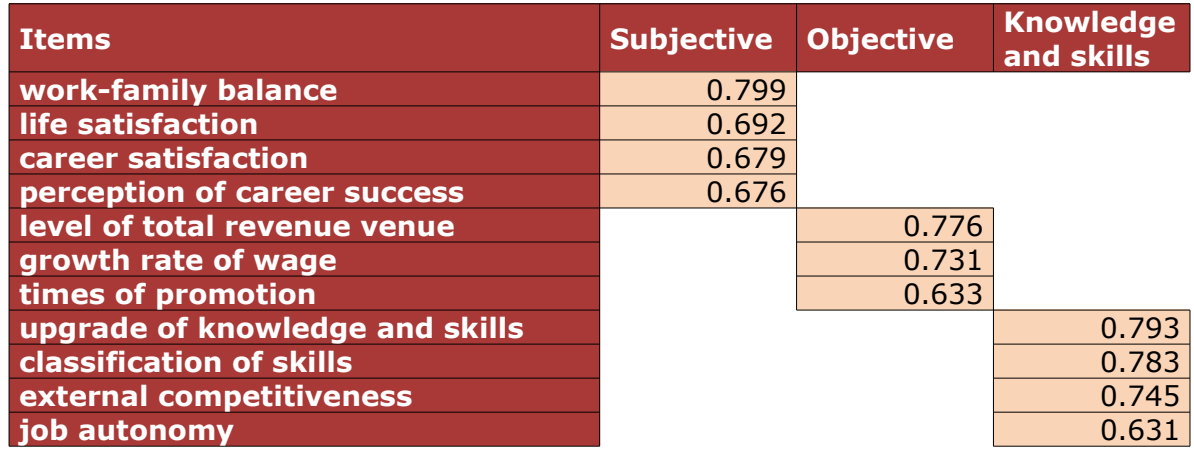

Table 4. Rotation factor loading matrix $(\mathrm{N}=230)$

According to the result of EFA, we extracted 3 dimensions. The first dimension means "subjective respect of success", including work-family balance, life satisfaction, career satisfaction, perception of career success. The second dimension means "objective respect of success", including level of total revenue venue, growth rate of wage, times of promotion. The third dimension means "skills and abilities respect of success", including upgrade of knowledge and skills, classification of skills, external competitiveness and job autonomy.

To specify the relationships between the observed measures and their posited underlying factors, we use AMOS20.0 to analysis the other samples. From the Table 5, it can be concluded that the model fit the data acceptably well, for $\mathrm{x}^{2} / \mathrm{df}=2.868$, and except for IFI is slightly lower than 0.9, NFI, TLI and CFI is much more than 0.9, RMSEA $=0.073$.

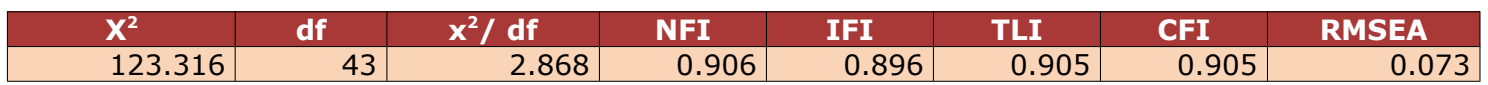

Table 5. The fitting degree index of structure confirmatory factor analysis of 3 factors

\subsection{Control Variables Analysis}

According to the classification criteria of age, job category, title of skilled employees, the survey object is divided into different groups, and takes variance analysis of different types of data. And uses Scheffe multiple comparison method to test the differences of the different categories of evaluation indicators of skilled employees' career success (due to space limitations, data is not shown).

The analysis results show that the choice of evaluation indicators of career success: the degree of attention to work-family balance and life satisfaction is significant different by different ages of skilled employees. Skilled employees at the age of 40-45 pay more attention to work-family balance than the age of 25-30 group. Skilled employees at the age of 35-40 pay more attention to life satisfaction than any other age group; And there are significant differences in the degree of attention to career satisfaction and employability between different titles of 
skilled employees, as the title of senior skilled employees pay more attention to career satisfaction than junior skilled employees, and the junior skilled employees do not attach much importance to the employability compared to other titles of skilled employees; And different positions, there are also significant differences in the degree of attention to the level of total revenue, the EMU drivers pay more attention to the level of total revenue than the EMU mechanics and the dispatchers.

\section{Discussion}

We conducted the evaluation indicators of skilled employees' career success from the analysis of grounded theory and investigation of questionnaire to railway industry employees, including three areas: subjective career success, objective career success and knowledge and skills career success. And working-family balance, life satisfaction, career satisfaction, perception of career success composed subjective career success, level of total revenue venue, growth rate of wage and times of promotion composed objective career success, upgrade of knowledge and skills, classification of skills, external competitiveness and job autonomy composed knowledge and skill career success. The results of subjective and objective career success supported the view that career success include subjective and objective career success of many scholars (Ballout, 2007; Chudzikowski, 2012).

In this study, working-family balance became the evaluation indicator of skilled employees' career success. On the one hand, the background of traditional Chinese cultural influences that most of Chinese people see family as the important part in their life, and there is no exception for skilled employees in the railway industry. In this context, Skilled employees pay great attention to family factors and use a variety of measures to try to maintain a balance of work and family; on the other hand, the phenomenon of "skill shortage" caused the heavy tasks, the stress of work pace of skilled employees, thus the work can easily affect family life. Therefore, more and more skilled employees regard the balance relationship between work and family as a representative indicator of career success indicator. A recent study has also shown that the intrinsic satisfaction, external compensation and work-family balance may be the important influences of career success for Chinese employees (Russo, Guo \& Baruch, 2014).

The study also concluded that knowledge and skills are considered as an important evaluation indicator of objective career success, which is relatively rare in previous studies. As the railway industry has its own characteristics, that the objective success of skilled employees as well has its specificity. For example, although there is no particular income gap between skilled employees namely "chief engineer" and "technical experts", they have high technical level, in other words, their objective success is mainly reflected by the level of skills, and compared with managers, they are more willing to upgrade their knowledge and skills to obtain higher skilled titles to realize their value. 


\section{Conclusion and Limitation}

Career success not only plays the role of excitation of professional conduct, but also reflects the values of a society. The evaluation indicators of career success of skilled employees helps organizations understand intrinsic motivation of this core group, and the organizations can effectively design and implement career development system to meet the needs of skilled employees, and to maximize to play a role in motivating skilled employees. Therefore, to think and research the evaluation indicators of career success deeply and systematicly is very necessary. Through interviews and questionnaires to railway skilled employees, the study established evaluation indicators indicators of skilled employees' career success, and explored differences between different ages, titles and positions of skilled employees. And the results will provides a useful reference for career management of skilled employees.

This study is not without limitations. First, our findings are based on self-report data and may be subject to common method variance. To validate our findings, future research may include more objective measures, for instance wage and promotion data from the employer. Secondly, it is important to mention the potential influence of our sample. We tested our model with a specific sample of railway skilled employees, However, because we focused on this specific sample, some of our findings may not be generalizable to other samples. It is also worthwhile to determine whether there are gender differences in career success of skilled employees in China. Women working in the railway industry constitute a significant proportion of the labor force, but not many can reach top managerial positions, as they are often discouraged from applying for executive positions. In addition, this study's findings point to the need to further conceptualize and operationalize career success of skilled employees.

\section{References}

Arthur, M.B., Khapova, S.N., \& Wilderom, C.P. (2005). Career success in a boundaryless career world. Journal of Organizational Behavior, 26(2), 177-202. http://dx.doi.org/10.1002/job.290

Arthur, M.B., \& Rousseau, D.M. (1996). The boundaryless career: A new employment principle for a new organizational era. New York: Oxford University Press.

Ballout, H.I. (2007). Career success: The effects of human capital, person-environment fit and organizational support. Journal of Managerial Psychology, 22(8), 741-765. http://dx.doi.org/10.1108/02683940710837705

Chudzikowski, K. (2012). Career transitions and career success in the 'new' career era. Journal of Vocational Behavior, 81(2), 298-306. http://dx.doi.org/10.1016/j.jvb.2011.10.005

Dries, N., Pepermans, R., \& Carlier, O. (2008). Career success: Constructing a multidimensional model. Journal of Vocational Behavior, 73(2), 254-267. 
Hall, D.T., \& Chandler, D.E. (2005). Psychological success: when the career is a calling. Journal of Organizational Behavior, 26(2), 155-176. http://dx.doi.org/10.1002/job.301

Heslin, P.A. (2005). Conceptualizing and evaluating career Success. Journal of Organizational Behavior, 26(2), 113-136. http://dx.doi.org/10.1002/job.270

Jansen, P.G.W., \& Vinkenburg, C.J. (2006). Predicting management career success from assessment center data: A longitudinal study. Journal of Vocational Behavior, 68(2), 253-266. http://dx.doi.org/10.1016/j.jvb.2005.07.004

Judge, T.A, Higgins, C.A., Thoresen, C.J., \& Barrick, M.R. (1999). The big five personality traits, general mental ability, and career success across the life span. Personnel Psychology, 52(3), 621-652. http://dx.doi.org/10.1111/j.1744-6570.1999.tb00174.x

London, M., \& Stumpf, S.A. (1982). Managing careers. Reading, MA: Addison-Wsley.

Nicholson, N., \& Waal-Andrews, W. (2005). Playing to win: Biological imperative, selfregulation, and trade-offs in the game of career success. Journal of Organizational Behavior, 26(2), 137-154. http://dx.doi.org/10.1002/job.295

Nunnally, J.C., \& Bernstein, I.H. (1978). Psychometric Theory. New York: McGraw-Hill.

Pachulicz, S., Schmitt, N., \& Kuljanin, G. (2008). A model of career success: A longitudinal study of mergency physicians. Journal of Vocational Behavior, 73(2), 242-253.

http://dx.doi.org/10.1016/j.jvb.2008.05.003

Russo, M., Guo, L., \& Baruch, Y. (2014). Work attitudes, career success and health: Evidence from China. Journal of Vocational Behavior, 84(3), 248-258.

http://dx.doi.org/10.1016/j.jvb.2014.01.009

Van Maanen, J. (1977). Experiencing organization: Notes on the meaning of careers and socialization. In Van Maanen, J. (ed.), Organizational careers: Some new perspectives. New York: Wiley.

Verbruggen, M. (2012). Psychological mobility and career success in the new career climate. Journal of Vocational Behavior, 81(2), 289-297. http://dx.doi.org/10.1016/j.jvb.2011.10.010

Journal of Industrial Engineering and Management, 2015 (www.jiem.org)

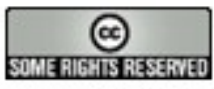

Article's contents are provided on a Attribution-Non Commercial 3.0 Creative commons license. Readers are allowed to copy, distribute and communicate article's contents, provided the author's and Journal of Industrial Engineering and Management's names are included. It must not be used for commercial purposes. To see the complete license contents, please visit http://creativecommons.org/licenses/by-nc/3.0/. 